\title{
PENTINGNYA RUBRIK PENILAIAN DALAM PENGUKURAN KEJUJURAN PESERTA DIDIK
}

\author{
Suwarno ${ }^{1}$, Candra Aeni ${ }^{2}$ \\ 1,2Pendidikan Ekonomi, Universitas PGRI Ronggolawe Tuban \\ Jalan Manunggal Nomor 61, Gedongombo, Semanding, Tuban, Jawa Timur \\ 2email: candraunirow@gmail.com
}

\begin{tabular}{|c|c|c|c|c|c|}
\hline $\begin{array}{c}\text { Submitted } \\
2021-01-16\end{array}$ & $\begin{array}{c}\text { Accepted } \\
2021-04-26\end{array}$ & $\begin{array}{l}\text { Published } \\
2021-05-21\end{array}$ & open Access & (c) (i) \& & Esukas: \\
\hline
\end{tabular}

\begin{abstract}
Abstrak
Pengembangan Kurikulum 2013 berbasis kompetensi diharapkan dapat meningkatkan kualitas peserta didik. Penilaian bertujuan untuk menilai perilaku peserta didik di dalam maupun di luar pembelajaran. Tujuan penulisan artikel untuk menguraikan pentingnya rubrik penilaian dalam pengukuran kejujuran peserta didik di SMA. Apabila efektivitas pengajaran kejujuran dapat dilakukan, maka akan menjadi landasan yang kuat untuk bangsa. Kejujuran merupakan salah satu sikap sosial. Penilaian kejujuran dapat dilakukan menggunakan observasi, penilaian diri, penilaian teman sejawat, serta jurnal. Instrumen yang digunakan pada jurnal berupa catatan pendidik. Sedangkan untuk observasi, penilaian diri, dan penilaian antarpeserta didik menggunakan instrumen berupa daftar cek atau skala penilaian yang disertai rubrik. Rubrik adalah alat penilaian yang memiliki deskripsi kinerja yang diharapkan setiap kriteria untuk mencapai nilai tertentu. Rubrik bisa analitik, holistik maupun keduanya yang dikombinasikan. Rubrik bermanfaat bagi peserta didik dan juga pendidik.
\end{abstract}

Kata Kunci: rubrik penilaian; kejujuran; peserta didik.

\begin{abstract}
Competency-based 2013 curriculum development hopes to improve the quality of students, The assessment aims to assess the behavior of students inside and outside of learning. The purpose of this article was to describe the importance of assessment rubrics in measuring the honesty of students in high school. If the effectiveness of teaching honesty can be carried out, it will create a strong foundation for the nation. Honesty is a social attitude. Assessment of honesty can be done using observation, self-assessment, peer assessment, and journals. The instrument used in the journal was in the form of educator notes. As for observation, self-assessment, and assessment among students using instruments in the form of a checklist or rating scale accompanied by a rubric. A rubric is an assessment tool that has a description of the expected performance of each criterion to achieve a certain value. Rubrics can be analytical, holistic, or both. A rubric is useful for students and educators.
\end{abstract}

Keywords: assessment rubric; honesty; students.

\section{PENDAHULUAN}

Salah satu tujuan pengembangan Kurikulum 2013 berbasis kompetensi adalah memberikan arah bagi peserta didik agar berkualitas, beriman, bertakwa, berakhlak mulia, berilmu, sehat, kreatif, cakap, dan mandiri. Kurikulum 2013 
diharapkan memberikan arahan supaya peserta didik berkompeten di bidang pengetahuan dan memiliki kepribadian yang kuat. Dalam Kurikulum 2013, terdapat penilaian sikap yang berguna untuk mengetahui sikap spiritual maupun sosial yang terjadi di dalam dan di luar pembelajaran. Sikap spiritual berhubungan dengan pembentukan keimanan dan ketakwaan. Sikap sosial berhubungan dengan akhlak yang mulia, kejujuran, bertanggung jawab, dan mandiri.

Penilaian dalam Kurikulum 2013 dilakukan pada beberapa aspek, yaitu unjuk kerja, produk, dan sikap. Jujur merupakan bagian dari sikap sosial. Penilaian dapat dilaksanakan pada waktu proses maupun berakhirnya proses pembelajaran. Permasalahan yang sering dihadapi pendidik pada penilaian adalah minimnya alat penilaian, baik domain pengetahuan, keterampilan maupun sikap pada waktu proses belajar-mengajar berlangsung. Sikap merupakan bagian dari ranah afektif. Penilaian pada ranah afektif meliputi penilaian watak perilaku seperti sikap, minat, konsep diri, nilai, dan moral (Saftari \& Fajriah, 2019). Sebagian besar pendidik tidak memperhatikan secara rinci pada ranah afektif peserta didik dalam proses pemberian nilai. Penggunaan instrumen oleh pendidik kurang sesuai dalam melakukan penilaian pada ranah afektif. Nilai "Baik" akan diberikan pendidik apabila peserta didik sudah melakukan pengumpulan tugas yang dibebankan kepada peserta didik (Balqis, 2020). Seharusnya predikat yang diberikan oleh pendidik diberi penjelasan (rubrik). Dengan rubrik, orang tua dapat memahami kemajuan sikap peserta didik secara nyata.

Penilaian aspek afektif dapat dilakukan menggunakan teknik observasi, penilaian diri, penilaian teman sejawat, serta jurnal. Instrumen yang digunakan pada jurnal berupa catatan pendidik. Sedangkan untuk observasi, penilaian diri, dan penilaian antarpeserta didik menggunakan instrumen berupa daftar cek atau skala penilaian yang disertai rubrik (Permendikbud, 2013). Berdasarkan hasil wawancara, pendidik belum melakukan penilaian dengan baik, contohnya pada ranah afektif. Ranah afektif dinilai menggunakan observasi tanpa menggunakan indikator yang tepat (Balqis, 2020). Pendidik melakukan penilaian terhadap peserta didik tidak menggunakan rencana sebagai acuan dan tidak menggunakan pedoman yang pasti (Linda, 2013). Realitas yang terjadi adalah kurangnya instrumen 
Edukasi: Jurnal Pendidikan, Volume 19 Nomor 1 Tahun 2021

Pentingnya Rubrik Penilaian dalam Pengukuran Kejujuran.......

Suwarno, Candra Aeni

Halaman 161-173

penilaian sikap, yaitu berupa rubrik. Rubrik sikap yang sudah dibuat oleh pendidik adalah rubrik untuk menilai sikap secara umum yang menyebabkan rubrik tersebut masih berlaku untuk semua materi. Seharusnya, masing-masing sikap menggunakan rubrik yang berbeda-beda.

Berdasarkan permasalahan yang telah diuraikan, maka penulisan artikel bertujuan untuk menguraikan pentingnya rubrik penilaian. Rubrik penilaian yang dibahas merupakan rubrik penilaian dalam mengukur tingkat kejujuran peserta didik. Pendidik yang memahami pentingnya rubrik penilaian diharapkan akan memberikan penilaian kepada peserta didik dengan pedoman yang jelas. Hasil penilaian kejujuran dapat diimplementasikan bukan hanya di sekolah, tetapi juga dapat diterapkan dalam kehidupan sehari-hari dan di dunia kerja.

\section{Kejujuran}

Jujur merupakan sesuatu yang menggambarkan keadaan sesungguhnya, terbuka, adanya kesesuaian antara sesuatu yang dilakukan dan apa yang dikatakannya (mempunyai integritas), adanya keberanian karena benar, amanah, atau dapat dipercaya (trustworthiness), serta tidak melakukan kecurangan (no cheating) (Moad \& Zuldafrial, 2019; Widiyanto \& Istiqomah, 2019; Lizawati, 2016; Samani \& Hariyanto, 2013). Secara harfiah, perilaku jujur mempunyai arti hati yang lurus, tidak melakukan kebohongan serta kecurangan (Naim, 2012). Jujur tidak hanya diucapkan, tetapi juga harus dicerminkan dalam perilaku sehari-hari. Perilaku jujur merupakan nilai penting yang harus dimiliki oleh setiap peserta didik. Jujur berarti mengakui kenyataan yang ada; adanya kesesuaian dalam berpikir, berucap, serta bertindak; mempunyai ketulusan dan tidak berlaku curang; serta kuat dan mempunyai keberanian (Erlangga, 2013). Kejujuran meliputi segala sesuatu, yang dimulai dengan adanya niat sampai terjadinya tindakan. Pikiran dan hati yang tenang akan diperoleh seseorang karena mempunyai sikap jujur.

Kejujuran sangat diperlukan pada saat melaksanakan kesepakatan, kewajiban maupun suatu tugas. Kejujuran dapat menjadikan kehidupan berkembang menjadi lebih baik, sementara kemunduran dalam segala hal akan terjadi karena tidak adanya kejujuran (Yaumi, 2016). Jadi kesimpulannya, kejujuran merupakan 
perbuatan dan perkataan yang dilakukan sesuai dengan keadaan yang nyata, tidak melakukan kecurangan, melaksanakan sesuai kesepakatan serta dapat dipercaya pada semua segi kehidupannya. Kejujuran merupakan inti dalam kehidupan. Kejujuran sebagai bagian dari sikap yang harus diberikan kepada peserta didik. Kejujuran adalah sifat yang penting dalam membentuk kepribadian peserta didik.

Pendidik menanamkan kejujuran secara efektif diharapkan akan menghasilkan pondasi yang kuat bagi suatu bangsa. Penilaian kejujuran di sekolah seharusnya menggunakan rubrik. Penggunaan rubrik dalam mengukur kejujuran akan menjadikan penilaian tersebut menggunakan acuan yang jelas. Hasil penilaian dengan menggunakan acuan yang jelas diharapkan akan mengurangi subjektivitas dalam penilaian.

\section{Rubrik Penilaian}

Rubrik merupakan alat penilaian yang memberikan gambaran kinerja yang diharapkan pada setiap kriteria untuk mencapai nilai atau hasil tertentu. Rubrik adalah metode sistematis untuk mengumpulkan data mengenai pengetahuan dan keterampilan. Rubrik dapat digunakan untuk mengukur perilaku tertentu (Garfolo et al., 2016). Secara rinci, rubrik adalah kuesioner penilaian skala dengan item respons terpilih (Haladyna \& Rogriguez, 2013). Rubrik memberikan harapan spesifik atau standar kinerja untuk mengevaluasi hasil pembelajaran (Stevens \& Levi, 2013). Bagian utama rubrik berguna sebagai alat penilaian dan alat belajar.

Penggunaan rubrik dalam penilaian akan memberikan deskripsi nyata atas kemampuan peserta didik. Kelebihan rubrik adalah memberikan informasi nyata atas capaian hasil belajar peserta didik yang diperolehnya. Penggunaan rubrik dapat memotivasi peserta didik untuk memperoleh capaian yang tinggi dan mengetahui kekurangan maupun kelebihan yang sudah dicapai. Penggunaan rubrik dalam penilaian memang sangat penting karena rubrik dapat digunakan untuk mengklasifikasi kualitas kemampuan belajar peserta didik. Rubrik membantu pendidik dalam kegiatan pengajaran di kelas; membantu mengkoordinasikan pengajaran dan nilai; serta membantu pembelajaran peserta didik (Brookhart, 
Edukasi: Jurnal Pendidikan, Volume 19 Nomor 1 Tahun 2021

Pentingnya Rubrik Penilaian dalam Pengukuran Kejujuran.......

Suwarno, Candra Aeni

Halaman 161-173

2013). Dengan adanya rubrik, peserta didik dapat mengetahui target pembelajaran yang harus dicapai dan kriteria untuk mencapai tujuan pembelajarannya.

Rubrik yang dikembangkan bisa secara holistik, analitik, atau kombinasi keduanya. Rubrik holistik adalah konstruk yang berisi macam-macam tingkatan pekerjaan yang mendeskripsikan kualitas, kuantitas suatu tugas, atau seluruhnya berupa kuantitas dan kualitas pekerjaan. Rubrik holistik mengharuskan seorang pendidik menentukan tingkat pekerjaan. Rubrik analitik merupakan rubrik yang memberikan penilaian masing-masing untuk setiap kriteria (Nurgiantoro, 2011). Rubrik holistik dan analitik adalah dua rubrik yang paling sering ditampilkan. Rubrik dapat dikategorikan menjadi model spesifik-tugas atau generik (Haladyna \& Rogriguez, 2013). Rubrik yang spesifik untuk suatu tugas mengacu pada model spesifik tugas. Rubrik yang digunakan untuk tugas yang tidak spesifik tetapi memiliki kriteria yang mirip dengan tugas tertentu disebut model generik. Model spesifik tugas paling baik digunakan untuk pembelajaran di kelas, sedangkan model generik lebih cocok untuk digunakan untuk tes dan ujian.

Rubrik holistik menggabungkan semua fitur analitis menjadi satu skor tunggal (Haladyna \& Rogriguez, 2013). Rubrik holistik lebih mudah untuk dikembangkan, tetapi tidak merinci tingkat kinerja peserta didik karena hanya skor tunggal yang diberikan untuk mengevaluasi pekerjaan peserta didik (Baryla et al., 2012). Rubrik holistik biasanya memiliki bagian ulasan untuk membenarkan apakah suatu tugas selesai atau tidak. Rubrik holistik merupakan rubrik yang digunakan untuk mengadakan penilaian tidak menggunakan kriteria secara terpisah (Brookhart, 2013). Penyusunan kriteria dan penskorannya tidak banyak memakan waktu. Kriteria dalam rubrik holistik mudah diinterpretasikan sehingga penilaian yang dihasilkan mempunyai reliabilitas yang tinggi (Brookhart, 2013). Interpretasi rubrik holistik yang mudah dilakukan menjadikan rubrik tersebut selain praktis juga tidak menimbulkan masalah meskipun penilaian kualitas atau keterampilan peserta didik dilakukan dua orang pendidik atau lebih.

Rubrik analitik adalah konstruk berisi ukuran dasar yang dibagi menjadi beberapa tingkat pekerjaan. Tiap-tiap bagian diawali dengan ukuran dasar tertentu yang akan dinilai dan tiap-tiap bagian mendeskripsikan tingkat ukuran dasar 
pekerjaan. Untuk menambah kejelasan sebuah rubrik analitik, setiap topik ukuran dasar dapat dibagi lagi menjadi pernyataan yang lebih singkat dan kemudian diikuti oleh deskripsi pekerjaan terkait. Rubrik analitik mendeskripsikan setiap kriteria secara terpisah (Brookhart, 2013). Pada rubrik analitik, pendidik dapat memberikan penilaian yang berbeda-beda menurut masing-masing kriteria.

Rubrik analitik menyediakan komponen terpisah untuk setiap tugas kepada peserta didik yang mungkin memiliki kesulitan dengan area penugasan spesifik. Komponen rubrik yang sangat penting terdiri dari kriteria singkat dari kinerja, skala rating, dan gambaran kinerja yang diharapkan pada setiap tingkatannya. Dalam rubrik analitik peserta didik perlu menampilkan sesuatu yang menunjukkan kemahiran, oleh karena dalam rubrik diperlukan desain yang memerlukan kriteria teridentifikasi secara jelas. Penilaian dalam rubrik analitik diberikan untuk tiap-tiap komponen dari tugas yang dikerjakan oleh peserta didik.

Rubrik analitik adalah sekumpulan skor kinerja untuk sejumlah kriteria evaluasi berbeda yang independen satu sama lain (Haladyna \& Rogriguez, 2013). Rubrik analitik merupakan rubrik yang banyak membutuhkan waktu untuk dikembangkan, tetapi skornya akan lebih akurat (Haladyna \& Rogriguez, 2013). Untuk membantu peserta didik dan pendidik mengidentifikasi tingkat kinerja melalui kriteria diskrit, rubrik analitik lebih tepat digunakan untuk penilaian (Garfolo et al., 2016). Pendidik yang menyusun rubrik analitik harus menjabarkan kriteria ke dalam deskripsi setiap kriteria secara bertingkat. Penyusunan rubrik analitik selain banyak membutuhkan waktu juga tergolong sulit. Kesulitan lainnya berupa pendidik yang menjadi penilai harus membuat konsepsi yang sama berkaitan dengan kriteria dan tingkat kualitasnya apabila kinerja peserta didik dinilai lebih dari dari satu pendidik. Sehingga kriteria yang ada pada rubrik harus dicocokkan satu demi satu oleh pendidik yang menjadi penilai pada penilaian rubrik analitik.

Prosedur yang baku belum ada dalam pengembangan rubrik, sebab rubrik adalah konstruksi yang mengacu pada tujuan dan harapan. Rubrik dikembangkan dalam satu kelas tidak akan berlaku untuk kelas lain. Namun memeriksa rubrik dari kelas lainnya merupakan bagian penting dari pengembangan rubrik di kelas. 
Edukasi: Jurnal Pendidikan, Volume 19 Nomor 1 Tahun 2021

Pentingnya Rubrik Penilaian dalam Pengukuran Kejujuran.......

Suwarno, Candra Aeni

Halaman 161-173

Dengan memeriksa rubrik dari kelas lain akan mengetahui bagaimana pendidik menggambarkan tingkat kinerja untuk tugas-tugas serupa dan bagaimana pendidik memenuhi berbagai kebutuhan peserta didik. Penilaian akan lebih relevan dengan kehidupan peserta didik dan dunia nyata. Rubrik memberikan penilaian yang lebih akurat, adil, dan nilai evaluasi lebih transparan yang dapat menghindari prasangka pribadi dan mengurangi kekhawatiran tentang tugas (Reynolds-Keefer, 2010).

Rubrik dapat disesuaikan dengan kemampuan dan kematangan peserta didik karena lebih deskriptif. Dengan demikian, rubrik mudah dipahami dan umpan balik lebih transparan serta konstruktif. Rubrik membantu peserta didik untuk fokus pada upaya belajar, menghasilkan pekerjaan dan tugas yang mempunyai kualitas lebih baik untuk mencapai nilai yang lebih baik. Dengan adanya umpan balik langsung kepada peserta didik tentang sesuatu yang sudah ataupun belum dipelajari, sehingga dapat digunakan sebagai evaluasi untuk diri sendiri dan dapat meningkatkan proses pembelajaran maupun karier masa depan.

Rubrik membantu pendidik dalam menilai kualitas pekerjaan seorang peserta didik. Rubrik juga memberi kerangka yang jelas bagi pendidik dan menjadi pedoman dalam melakukan penilaian untuk mengidentifikasi tingkat pencapaian kriteria yang dievaluasi (Spence, 2010). Rubrik memberi manfaat bagi pendidik dalam mengevaluasi semua domain belajar dan mencegah pendidik memberi penilain secara bias kepada peserta didik. Walaupun menggunakan rubrik yang berbeda, akan tetapi hasil penilaian tetap sama atau terstandar secara jelas (Knight et al., 2010). Rubrik dapat mendorong kontak antara pendidik dan peserta didik, pembelajaran aktif, serta memberikan umpan balik yang cepat. Rubrik menjadi alat yang efektif untuk menilai pembelajaran yang dilakukan. Keterbatasan menggunakan rubrik untuk penilaian berakar dalam konstruksi rubrik. Hal tersebut disebabkan penulisan rubrik tidak dilakukan secara baik. Penyusunannya membutuhkan waktu yang lama, walaupun biaya yang dikeluarkan murah. Pendidik belum tahu bagaimana membuat rubrik yang baik, dengan demikian prosesnya akan memakan waktu terlalu banyak (Balqis, 2020).

Terdapat kekhawatiran dalam menggunakan rubrik. Namun demikian, rubrik yang dirancang dan dirumuskan dengan baik dan benar dapat menjadi alat evaluasi 
yang efektif untuk pendidikan. Secara keseluruhan, rubrik dapat menjadi bantuan belajar bagi peserta didik yang berharga. Dengan membuat tujuan yang jelas, peserta didik akan memiliki pemahaman lebih baik akan tugas yang diberikan dan belajar lebih efektif karena nilai akan lebih bermakna, serta evaluasi akan lebih konsisten. Tanpa alat evaluasi yang dapat diandalkan, masalah inkonsistensi dan subjektivitas dapat merusak proses evaluasi dalam program pendidikan yang mengarah ke sengketa pemberian nilai dan kegagalan.

\section{Rubrik Penilaian Kejujuran Peserta Didik}

Langkah awal dalam mengembangkan rubrik penilaian sikap jujur adalah menentukan sikap jujur dan standar unjuk kerja sikap jujur yang akan dinilai. Kompetensi merupakan kemampuan seseorang dalam melaksanakan suatu pekerjaan secara benar serta adanya keunggulan berdasarkan segala sesuatu yang berkaitan dengan pengetahuan, keahlian, dan sikap (Edison et al., 2016). Kemudian setiap kompetensi dijabarkan ke dalam kompetensi dasar dan dari masing-masing kompetensi dasar dijabarkan lagi menjadi beberapa indikator. Indikator adalah bukti tercapainya kompetensi dasar yang dibuktikan dengan berubahnya perilaku yang terukur.

Suatu pedoman harus digunakan dalam penetapan standar unjuk kerja sikap jujur. Hal tersebut akan menghasilkan hasil penilaian yang konsisten meskipun dilakukan oleh penilai berbeda dan waktu yang berbeda pula untuk objek yang sama. Apabila skor dinyatakan dalam skala penilaian, maka harus dibuat kriteria dari masing-masing skala yang dibuat untuk setiap indikator. Skor harus mempunyai makna, adil, dan kesalahan pengukurannya kecil. Penilaian unjuk kerja pada prinsipnya berdasarkan pada acuan kriteria yang merupakan pedoman penentuan suatu unjuk kerja apakah telah mencapai standar atau belum.

Tahapan-tahapan yang dilakukan dalam menyusun rubrik, yaitu: (1) Memikirkan dan melakukan analisis kompetensi yang akan diukur; (2) Menguraikan kompetensi dasar menjadi beberapa hal yang memberikan penjelasan; (3) Menyeleksi tugas-tugas yang harus dilakukan; (4) Menulis dan membuat format penilaian; dan (5) Menentukan ketentuan pemberian skor (Wang, 
Edukasi: Jurnal Pendidikan, Volume 19 Nomor 1 Tahun 2021

Pentingnya Rubrik Penilaian dalam Pengukuran Kejujuran.......

Suwarno, Candra Aeni

Halaman 161-173

2010). Berdasarkan uraian tersebut, perlu pengembangan instrumen penilaian unjuk kerja yang menyeluruh dan mudah digunakan. Instrumen penilaian kejujuran pada pembelajaran berupa lembaran pengamatan pendidik, lembaran penilaian diri, dan lembaran penilaian sesama siswa berupa cheklist (Balqis, 2020). Try out penggunaan rubrik penilaian sikap bisa dilaksanakan beberapa kali supaya pendidik bertambah terampil saat melaksanakan penilaian sikap. Lembaran pengamatan untuk penilaian sikap, secara menyeluruh dalam satu alat perlu dikembangkan lagi.

Pendidik mata pelajaran Pendidikan Agama Islam (PAI) memiliki peran dalam penanaman kejujuran kepada peserta didik. Peran tersebut dapat meningkatkan mutu pendidikan dalam konsep pendidikan sistem ganda di SMK. Pendidik mata pelajaran PAI seharusnya memiliki strategi dan metode yang tepat dalam penyampaian materi pembelajaran PAI kepada peserta didik. Kejujuran yang diajarkan di sekolah diharapkan dapat diimplementasikan peserta didik ketika magang di dunia usaha dan industri. Hal tersebut berarti pembelajaran PAI yang diajarkan di sekolah seharusnya tidak hanya berupa pengetahuan, tetapi juga menyangkut sikap dan keterampilan (Munawarodin, 2015).

Peran pendidik bimbingan konseling juga besar terhadap penanaman karakter, termasuk didalamnya sikap spritual yaitu kejujuran. Pendidik dapat melakukan penelitian mengenai kecurangan akademik, termasuk bermacammacam cara perilaku peserta didik yang mendatangkan keuntungan dengan cara tidak jujur. Apabila hasil penelitian menunjukkan peserta didik banyak melakukan kecurangan, maka data tersebut dapat digunakan pendidik bimbingan konseling untuk melakukan pembinaan dan penanaman karakter melalui bimbingan individu sebagai upaya pencegahan kecurangan/ketidakjujuran pada waktu yang akan datang (Firna, 2016).

Pengembangan karier merupakan salah satu layanan pendidik bimbingan dan konseling untuk membantu peserta didik memahami dan menilai informasi, memilih serta mengambil keputusan karier. Pendidik bimbingan dan konseling berfungsi memberi informasi mengenai pentingnya kejujuran agar setelah lulus peserta didik mampu menyesuaikan diri serta dapat bertahan di lingkungan kerja. 
Pendidik bimbingan dan konseling juga berfungsi sebagai pemberi motivasi kepada semua perilaku peserta didik dalam meningkatkan potensi peserta didik, termasuk bersikap jujur dan komitmen terhadap pekerjaan. Pendidik bimbingan dan konseling sebagai tokoh berfungsi menyebarkan pengetahuan yang dimiliki untuk menumbuhkan nilai religius termasuk pentingnya kejujuran pada orientasi karier peserta didik. Strategi pendidik bimbingan dan konseling bersama-sama dengan semua pihak di sekolah dalam meningkatkan motivasi, religiositas, dan orientasi karier peserta didik. Strategi pendidik bimbingan dan konseling yang lain berupa selalu memperbaharui informasi mengenai dunia kerja dan memberi bekal mengenai dunia industri (Muslih, 2017).

Penanaman kejujuran juga dapat diajarkan melalui kantin kejujuran. Kantin kejujuran yang bermunculan di sekolah-sekolah merupakan bentuk partisipasi sekolah dalam mewujudkan pendidikan karakter bagi peserta didik. Kantin kejujuran juga didirikan di SMA Negeri 13 Semarang dengan nama Kanjusera yang merupakan singkatan dari kantin jujur, sehat, dan wirausaha. Peserta didik diharapkan mengambil barang yang dibeli, membayar, dan mengambil uang kembalian secara jujur. Pada waktu tertentu pengelola mengadakan pengawasan dan pembinaan kepada peserta didik yang berlaku tidak jujur. Kanjusera berhasil menjadi sarana untuk menumbuhkembangkan karakter jujur pada peserta didik di sekolah tersebut dan menjadi sarana menumbuhkan jiwa dan semangat berwirausaha (Latifah, 2017).

\section{SIMPULAN}

Rubrik penilaian sikap kejujuran direkomendasaikan sebagai salah satu bentuk asesmen. Rubrik memberi input dan follow up (tanggapan) guna meningkatkan kinerja dan sebagai upaya yang baik untuk menjelaskan harapan terhadap peserta didik. Hambatan utama dalam penyusunan rubrik adalah perumusan tingkatan yang menjadi petunjuk unjuk kerja yang menyeluruh, dapat diteliti, dan mudah diamati. Tahapan-tahapan yang dilakukan dalam penyusunan rubrik yaitu memikirkan dan melakukan analisis kompetensi yang akan diukur; menguraikan kompetensi dasar menjadi beberapa hal yang dapat memberikan 
Edukasi: Jurnal Pendidikan, Volume 19 Nomor 1 Tahun 2021

Pentingnya Rubrik Penilaian dalam Pengukuran Kejujuran.......

Suwarno, Candra Aeni

Halaman 161-173

gambaran terhadap kompetensi dasar; menyeleksi tugas-tugas yang harus dilakukan; menulis dan membuat format penilaian serta menentukan ketentuan pemberian skor.

\section{UCAPAN TERIMA KASIH}

Penulis mengucapkan terima kasih kepada CGPro karena telah memberikan bantuan dana untuk penerbitan artikel dengan Nomor 653/071073/PGRI/AK/ $\mathrm{VI} / 2020$.

\section{DAFTAR PUSTAKA}

Balqis, N. M. (2020). Pengembangan instrumen penilaian sikap jujur pada pembelajaran Bahasa Perancis berbasis Kurikulum 2013 di SMA Negeri 2 Wonosobo. Skripsi: Universitas Negeri Yogyakarta. Tidak dipublikasikan.

Baryla, E., Shelley, G., \& Trainor, W. (2012). Transforming rubrics using factor analysis. Practical Assessment, Research \& Evaluation, 17(4), 1-7. https://doi.org/10.7275/5nt2-g458.

Brookhart, S. M. (2013). How to create and use rubrics for formative assesment and grading. Alexandria, USA: ASCD.

Edison, E., Anwar, Y., \& Komariyah, I. (2016). Manajemen sumber daya manusia. Bandung: Alfabeta.

Erlangga, Y. (2013). Pendidikan anti korupsi. Jakarta: Erlangga Group.

Firna, S. D. (2016). Analisis kecurangan akademik melalui rubrik penskoran pada kajian masalah ekonomi. Jurnal Promosi, 4(2), 23-35.

Garfolo, B. T., Kelpsh, E. P., Phelps, Y., \& Kelpsh, L. (2016). The use of course embedded signature assignments and rubrics in programmatic assessment. Academy of Business Journal, 1(1), 8-20.

Haladyna, T. M., \& Rogriguez, M. C. (2013). Developing and validating test items. New York: Routledge.

Knight, J., Allen, S., \& Tracy, D. (2010). Using six sigma methods to evaluate the reliability of a teaching assessment rubric. The Business Review, 15(1), 1-6. 
Latifah, F. A. (2017). Menumbuhkembangkan karakter siswa SMA N 13 Semarang melalui Kanjusera. Jurnal Profesi Keguruan, 3(1), 16-24. https://dx.doi.org/10.15294/jpk.v3i1.9624.

Linda, M. (2013). Proses penilaian ranah afektif pada mata pelajaran IPS kelas IV di Sekolah Dasar Inti Kecamatan Piyungan. Skripsi: Universitas Negeri Yogyakarta. Tidak dipublikasikan.

Lizawati. (2016). Pendidikan karakter tokoh wanita dalam novel Layar Terkembang karya Sultan Takdir Alisjahbana. Jurnal Pendidikan Bahasa, 5(1), 116-127. http://dx.doi.org/10.31571/bahasa.v5i1.304.

Moad \& Zuldafrial. (2019). Implementasi pendidikan karakter dalam pembelajaran Pendidikan Kewarganegaraan di SMP Bumi Khatulistiwa. Jurnal Pendidikan Kewarganegaraan, 3(2),153-166. http://dx.doi.org/ 10.31571/pkn.v3i2.1438.

Munawarodin, M. (2015). Penanaman kejujuran dalam diri peserta didik selaras dengan pengembangan mutu pendidikan Islam sesuai konsep link and match di SMK Ma'arif 1 Yogyakarta. Skripsi: UIN Sunan Kalijaga. Tidak dipublikasikan.

Muslih, M. (2017). Upaya guru bimbingan dan konseling memaksimalkan orientasi karir siswa menggunakan pendekatan agama dan psikologi. Tesis: UIN Sunan Kalijaga. Tidak dipublikasikan.

Naim, N. (2012). Character building optimalisasi peran pendidikan dalam pengembangan ilmu \& pembentukan karakter bangsa. Yogyakarta: ArRuzz Media.

Nurgiantoro, B. (2011). Penilaian otentik (dalam pembelajaran bahasa). Yogyakarta: Gadjah Mada University Press.

Peraturan Menteri Pendidikan dan Kebudayaan (Permendikbud) Republik Indonesia Nomor 66 Tahun 2013 tentang Standar Penilaian Pendidikan dalam https://luk.staff.ugm.ac.id/atur/bsnp/Permendikbud66-2013SPenilaian. pdf. Diakses 31 Januari 2021. 
Reynolds-Keefer, L. (2010). Rubric-referenced assessment in teacher preparation: An opportunity to learn by using. Practical Assessment, Research \& Evaluation, 15(8), 1-9. https://doi.org/10.7275/psk5-mf68.

Saftari, M., \& Fajriah, N. (2019). Penilaian ranah afektif dalam bentuk penilaian skala sikap untuk menilai hasil belajar. Edutainment: Jurnal Ilmu Pendidikan dan Kependidikan, 7(1), 71-81. https://doi.org/10.35438/ e.v7i1.164.

Samani, M., \& Hariyanto. (2013). Konsep dan model pendidikan karakter. Bandung: Remaja Rosdakarya.

Spence, L. K. (2010). Discerning writing assessment: Insights into an analytical rubric. Language Arts, 87(5), 337-350.

Stevens, D. D., \& Levi, A. J. (2013). Introduction to rubrics: An assessment tool to save grading time, convey effective feedback, and promote student learning (2nd ed.). Sterling, VA: Stylus Publishing.

Wang, T. H. (2010). Web-based dynamic assessment: Taking assessment as teaching and learning strategy for improving students' e-learning effectiveness. Computers \& Education, 54(4),1157-1166. https://doi.org/ 10.1016/ j.compedu.2009.11.001.

Widiyanto, D., \& Istiqomah, A. (2019). Pembinaan kesadaran bela negara melalui budaya sekolah. Jurnal Pendidikan Kewarganegaraan, 3(2),153-166. http://dx.doi.org/10.31571/pkn.v3i2.1438.

Yaumi, M. (2016). Pendidikan karakter landasan, pilar \& implementasi. Jakarta: Prenada Media Group. 